\title{
Wildfire patterns and landscape changes in Mediterranean oak woodlands
}

\author{
N. Guiomar ${ }^{\mathrm{a}, \mathrm{b}, *}$, S. Godinho ${ }^{\mathrm{a}, \mathrm{b}}$, P.M. Fernandes ${ }^{\mathrm{c}, \mathrm{d}}$, R. Machado ${ }^{\mathrm{a}, \mathrm{b}}$, N. Neves ${ }^{\mathrm{b}, \mathrm{e}}$, J.P. Fernandes ${ }^{\mathrm{a}, \mathrm{b}}$ \\ a ICAAM, Institute of Mediterranean Agricultural and Environmental Sciences, University of Évora, Núcleo da Mitra, Apt. 94, 7002-554 Évora, Portugal \\ ${ }^{\mathrm{b}}$ Department of Landscape, Environment and Planning, University of Évora, Colégio Luis António Verney, Rua Romão Ramalho 59, 7000-671 Évora, Portugal \\ c CITAB, Centre for the Research and Technology of Agro-Environmental and Biological Sciences, University of Trás-os-Montes and Alto Douro, UTAD, Quinta de Prados, 5000-801 Vila Real, Portugal \\ 'CEABN InBio, Center for Applied Ecology "Prof. Baeta Neves", Institute of Agronomy, University of Lisbon, Portugal \\ e e-GEO, Research Centre for Geography and Regional Planning, Faculty of Social Sciences and Humanities, New University of Lisbon, Avenida de Berna, 1069-061 Lisboa, Portugal
}

\section{H I G H L I G H T S}

- Transitions in Mediterranean oak woodlands (montados) were assessed;

- Low spatial connectedness in montado landscape increases its vulnerability;

- Changes were mostly explained by fire characteristics and spatial factors;

- Large fires have a major role in transitions from montado to pioneer communities.

\section{A R T I C L E I N F O}

\section{Article history:}

Received 13 March 2015

Received in revised form 15 July 2015

Accepted 16 July 2015

Available online $\mathrm{xxx}$

Editor: J. P. Bennett

\section{Keywords:}

Agroforestry systems

Landscape change

Quercus spp.

Spatial fire patterns

Shrub encroachment

Large fires
G RAPHICALA B S TRACT

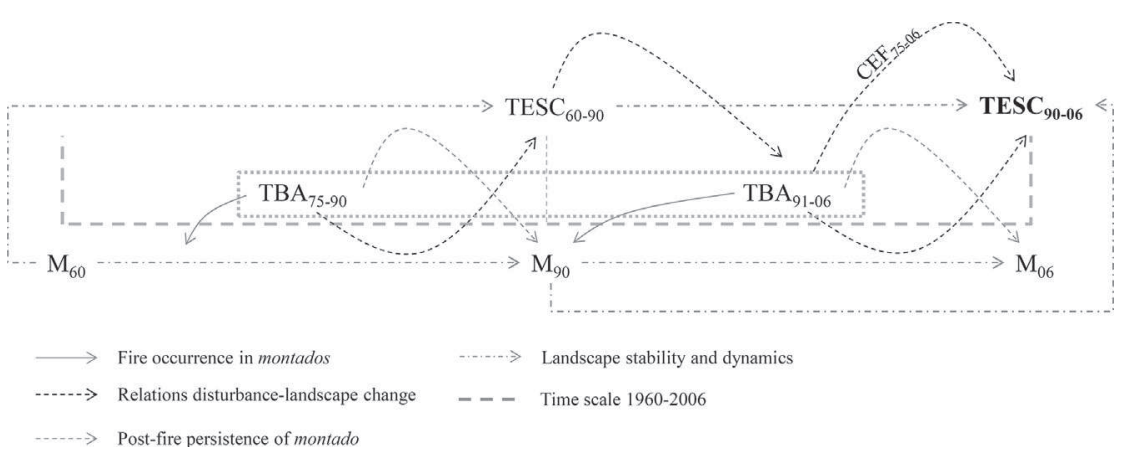

\begin{abstract}
A B S T R A C T
Fire is infrequent in the oak woodlands of southern Portugal (montado) but large and severe fires affected these agro-forestry systems in 2003-2005. We hypothesised transition from forest to shrubland as a fire-driven process and investigated the links between fire incidence and montado change to other land cover types, particularly those related with the presence of pioneer communities (generically designed in this context as "transitions to early-successional communities"). We present a landscape-scale framework for assessing the probability of transition from montado to pioneer communities, considering three sets of explanatory variables: montado patterns in 1990 and prior changes from montado to early-successional communities (occurred between 1960 and 1990), fire patterns, and spatial factors. These three sets of factors captured $78.2 \%$ of the observed variability in the transitions from montado to pioneer vegetation. The contributions of fire patterns and spatial factors were high, respectively $60.6 \%$ and $43.4 \%$, the influence of montado patterns and former changes in montado being lower (34.4\%). The highest amount of explained variation in the occurrence of transitions from montado to earlysuccessional communities was related to the pure effect of fire patterns (19.9\%). Low spatial connectedness in montado landscape can increase vulnerability to changes, namely to pioneer vegetation, but the observed changes were mostly explained by fire characteristics and spatial factors. Among all metrics used to characterize fire patterns and extent, effective mesh size provided the best modelling results. Transitions from montado to pioneer communities are more likely in the presence of high values of the effective mesh size of total burned area. This
\end{abstract}

\footnotetext{
* Corresponding author at: ICAAM, Institute of Mediterranean Agricultural and Environmental Sciences, University of Évora, Núcleo da Mitra, Apt. $94,7002-554$ Évora, Portugal. E-mail addresses: nunogui@uevora.pt (N. Guiomar),godinho.sergio@gmail.com (S. Godinho), pfern@utad.pt (P.M. Fernandes), rdpm@uevora.pt (R. Machado), nneves@uevora.pt (N. Neves), jpaf@uevora.pt (J.P. Fernandes).
} 